\title{
Sustainable employability for older workers: an explorative survey of belgian companies
}

\author{
Mathieu Verbrugghe ${ }^{1,2^{*}}$, Yoline Kuipers ${ }^{3}$, Bart Vriesacker ${ }^{1}$, $\|$ se Peeters ${ }^{1}$ and Katrien Mortelmans ${ }^{1}$
}

\begin{abstract}
Background: The European Agency for Safety and Health at Work (EU-OSHA) is developing an online e-guide, which will provide tips and practical information for each EU country (in their national language(s)) on ageing and occupational health and safety. The e-guide will be launched in 2016 as part of the EU-OSHA campaign on Healthy Workplaces for all ages. The e-guide will present evidence, tools and practical examples of how companies can take action and effectively promote sustainable employability.

Methods: As part of the development of the e-guide, a cross-sectional study was conducted to survey Belgian employers in April 2015 to determine their specific needs concerning older workers' occupational health and safety issues. Researchers from Milieu Ltd. (Brussels, Belgium), the consultancy company coordinating the e-guide project, and Mensura Occupational Health Services (Brussels, Belgium) developed a 13-item questionnaire. The survey addressed the needs and importance given to sustainable employability of older workers in Belgian companies and evaluated corporate knowledge regarding relevant national policies. The questionnaire was distributed electronically to the management of 22,084 private-sector companies affiliated with Mensura.
\end{abstract}

Results: Ten percent $(n=2133)$ of recipients opened the e-mail, and $37 \%(n=790)$ of these completed the questionnaire. In $89 \%$ of the responding companies, sustainable employability of workers aged $\geq 55$ years plays an important role; $70 \%$ have no active sustainable employability policy/initiative; $18 \%$ experience difficulties promoting sustainable employability; and $86 \%$ indicate no need for support to promote sustainable employability. Respondents noted the following health complaints among workers aged $\geq 55$ years: work-related health problems (31\%), stress (26\%), work agreements/type of work (17\%), work/life balance (15\%), and career development and/ or training (9\%). Topics concerning health and well-being of workers aged $\geq 55$ years requiring the most attention include motivation (30\%) and adaptation of the workplace to their health requirements (26\%).

Conclusions: The e-guide should raise further awareness among employers about the importance of implementing an active sustainable employability policy to prolong working life in a healthy and productive way. The e-guide should also include tools to address work-related health problems and stress, motivation, and adaptation of the workplace to the health requirements of workers aged $\geq 55$ years.

Keywords: Sustainable employability, Belgium, Older workers, Occupational health, Collective labour agreement

\section{Background}

The population of the European Union (EU) is ageing as a result of increasing life expectancy and low birth rates [1]. Consequently, the workforce is ageing and the proportion of working people decreasing, which impacts social security systems. The EU employment rate for the population aged 55-64 years increased from $38.4 \%$ in

\footnotetext{
* Correspondence: Mathieu.Verbrugghe@mensura.be

${ }^{1}$ Mensura Occupational Health Services, Brussels, Belgium

2Department of Public Health, Ghent University, Ghent, Belgium

Full list of author information is available at the end of the article
}

2002 to $51.8 \%$ in 2014 [1]. In Belgium, the employment rate for older individuals is lower than the EU average; in 2014, only $42.7 \%$ of the Belgian population 55-64 years old was employed.

To address the current and future impact of the ageing population, it is important to increase employment levels of all workers-including levels of older workers. The goal is to prolong working life and ensure that older workers maintain good health so they are able to work until retirement age, or even extend their professional 
careers beyond that point. In Belgium, to counteract the low employment rates among workers aged $\geq 55$ years, the federal government approved measures such as the Experience Fund, which offers financial support to companies with targeted initiatives to retain or improve work ability of older workers (e.g., increasing employability by means of training and skills enhancement). Additionally, the government raised the official retirement age from 65 to 66 years by 2025 and to 67 by 2030 .

Employers are challenged to keep ageing workers motivated and employable without threatening their wellbeing [2]. The concept of sustainable employability has received much attention in the last few years. Van der Klink et al. [3] defined sustainable employability as "workers having the opportunity to perform work with preservation of good health and wellbeing in current and future working life".

In Belgium, a mandatory collective labour agreement (CLA 104) was introduced in 2013 to support the sustainable employability of workers aged $\geq 45$ years. CLA 104 obligates companies in the private sector with more than 20 workers to develop and implement a concrete action plan to promote the employment of workers $\geq 45$ years, e.g., by introducing flexible work schedules, developing health promotion programs, and organizing customized trainings. Additionally, at the EU level, the European Agency for Safety and Health at Work (EU-OSHA) is developing as part of their Healthy Workplaces Campaign 2016-2017 an online e-guide entitled: 'Healthy Workplaces for all Ages' (project title: 'Development of an online multilingual e-guide to support companies in occupational safety and health $(\mathrm{OSH})$ management in the context of an ageing workforce' Open Tender Procedure No. EUOSHA-PRU/2014/P-3 https://www.healthy-workplaces.eu/). The e-guide will support workers, employers, Human Resources managers, and OSH professionals to address ageing at work and to promote the health and safety of older workers, and will consist of national versions that are adapted to the context and languages of EU countries.

As part of the development phase of the national version of the e-guide for Belgium, we explored employers' views on sustainable employability of older workers and their needs. The aims of our study are to explore how employers address ageing at the workplace, determine which $\mathrm{OSH}$ difficulties and barriers concerning worker ageing the companies are confronted with, and understand how companies promote sustainable employability (including CLA 104). Insight into these topics is important for adapting guidelines to current practices and needs.

\section{Methods}

In the preparation phase of the master version of the e-guide, Milieu Ltd (coordinator of the EU-project) collaborated with Mensura Occupational Health Services (OHS) in order to reach Belgian employers and to assess their needs regarding sustainable work and how to promote employability among older workers. This cross-sectional study of Belgian companies was conducted between April 21, 2015 and April 29, 2015. A questionnaire was developed by a team of OSH researchers. The questionnaire consisted of 13 items: four items identify general characteristics (the function of the respondent, sector of activities, number of workers, and percentage of workers $\geq 55$ years-old); five questions about the importance, needs, and concerns about sustainable employability in the company; and four questions concerning the knowledge and needs about sustainable employability policy. An-e-mail with an invitation to complete the online questionnaire was sent to the management of private-sector companies $(n=22,084)$ affiliated with Mensura OHS in Belgium. After three days, a reminder was sent.

\section{Results \\ General characteristics}

Ten percent of recipients $(n=2133)$ opened the e-mail, and within this group, $37.0 \%(n=790)$ completed the questionnaire (convenience sample). Respondents comprised $44.3 \%$ directors, $23.7 \%$ prevention advisors, $14.9 \%$ human resources managers, and $17.2 \%$ others. The most common sectors were: construction industry (21.9\%), other services (16.9\%), industry (13.5\%), human health and social work activities (9.2\%), and wholesale and retail trade and repair of motor vehicles and motorcycles $(8.4 \%)$. The numbers of workers in the companies were: $1-9$ (38.4 \%), 10-19 (16.7\%), 20-49 (16.7\%), 50-249 (19.7\%), 250-499 (4.3\%), and $\geq 500$ (4.2\%). Most companies had less than $20 \%$ of workers $\geq 55$ years old (70.5\%); $24.8 \%$ reported having $20-50 \%$ of their workers $\geq 55$ years old, and $4.7 \%$ had $>50 \%$ workers $\geq 55$ years old.

\section{Sustainable employability}

Sustainable employability played a role (i.e. having special attention for the sustainable employability of workers $\geq 55$ years old by e.g. having a policy, relevant initiatives or programmes) in most of the companies $(89.4 \%)$. Most of the companies did not have an active policy or initiative $(69.3 \%)$. Table 1 shows the reported topics concerning health and well-being of workers $\geq 55$ years old that require special attention in the companies and the reported complaints of workers $\geq 55$ years old.

Eighteen percent of the respondents experienced difficulties promoting sustainable employability of older workers. The reported difficulties were: lack of financial resources $(23.5 \%, n=42)$, lack of know-how $(22.3 \%, n=40)$, lack of interest of other managers to invest in sustainable 
Table 1 Topics concerning health and well-being of workers $\geq 55$ years that require special attention and reported complaints of workers $\geq 55$ years

\begin{tabular}{lll}
\hline & $\mathrm{n}$ & $\%$ \\
\hline $\begin{array}{l}\text { Topics concerning health and well-being of workers } \geq 55 \text { years } \\
\text { old that require special attention }\end{array}$ & \\
Keep workers $\geq 55$ years old motivated and involved & 309 & $29.6 \%$ \\
Adapting work(place) to the (health) needs of & 269 & $25.7 \%$ \\
workers $\geq 55$ years old & & \\
Supporting workers $\geq 55$ years old to maintain a & 167 & $16.0 \%$ \\
good work-life balance & & \\
Prevention of illness or accidents in & 111 & $10.6 \%$ \\
workers $\geq 55$ years old & & \\
Identifying risks for workers $\geq 55$ years old & 96 & $9.2 \%$ \\
Dealing with chronic or long-term diseases in & 93 & $8.9 \%$ \\
workers $\geq 55$ years old & & \\
Reported complaints of workers $\geq 55$ years old & 255 & $30.7 \%$ \\
Work-related health problems & 212 & $25.5 \%$ \\
Stress & 142 & $17.1 \%$ \\
Agreements on work and type of work & 122 & $14.7 \%$ \\
Work-life balance & 76 & $9.2 \%$ \\
Career development and/or training & 9 & $1.1 \%$ \\
Complaints related to safety & 7 & $0.8 \%$ \\
Discrimination & 7 & $0.8 \%$ \\
Harassment at work (bullying, violence, \\
and sexual harassment)
\end{tabular}

employability $(21.8 \%, n=39)$, lack of time (19.6\%, $n=35)$, and lack of participation of workers in relevant initiatives $(12.8 \%, n=23)$.

Topics reported to be difficult to discuss with workers $\geq 55$ years old were: the general ageing process and the impact on work (23.8 \%, $n=118)$, stress $(12.7 \%$, $n=63)$, long-term and chronic diseases $(12.5 \%, n=62)$, flexible working hours $(11.1 \%, n=55)$, career development $(10.7 \%, n=53)$, general health problems $(9.7 \%$, $n=48)$, pension issues $(9.3 \%, n=46)$, work-life balance $(7.3 \%, n=36)$, and disability $(2.8 \%, n=14)$.

\section{Collective labour agreement 104 (CLA 104)}

Almost half of the respondents $(n=380 ; 47.9 \%)$ stated they do not know that since $01 / 01 / 2013$, for companies in the private sector with $>20$ workers, it is mandatory to have a concrete action plan to promote the employment of workers $\geq 45$ years old. Of the respondents whose company is required to develop a CLA 104 policy (>20 workers): $47.2 \%(n=180)$ had one, $34.4 \%(n=131)$ will develop this in the short term, and $18.4 \%(n=70)$ did not intend to do this.

Main focuses of the developed or planned CLA 104 policy were reported as: valuing the accumulated knowledge and experience $(16.6 \%, n=333)$, ergonomic measures $(13.8 \%, n=276)$, age-related reduction in working hours $(9.8 \%, n=196)$, recruitment $(8.6 \%, n=173)$, training $(8.4 \%, n=169)$, psychosocial measures $(7.8 \%$, $n=156)$, job matching $(6.5 \%, n=130)$, age-related flexible work schedules (5.2 \%, $n=104)$, sick leave policy $(5.0 \%, n=100)$, spontaneous consultation with the OSH physician ( $4.8 \%, n=97)$, health promotion $(4.2 \%, n=85)$, check-up examinations $(4.0 \%, n=81)$, and others $(5.2 \%$, $n=105)$.

\section{Discussion}

Our study showed that, in most Belgian companies, sustainable employability of ageing workers is important; however, most companies do not yet have an active policy or initiative on this issue. These results underline the need for both Belgian and European support for employers to address an ageing workforce.

The annual report of the Experience Fund [4] showed that, despite the trend of an increasing number of applications, the Fund remains underutilized. Our study supports this finding. Based on the own study results and the annual report of the Experience Fund [4], we recommend that the Belgian government more extensively promotes the Experience Fund.

The results of this study will be used for the further development of the EU e-guide, and will ensure that it will: a) further increase employer awareness about the importance of implementing an active sustainable employability policy to prolong working life and productivity and b) include tools to address work-related health problems and stress, motivation, and workplace adaptation to the (health) requirements of workers aged $\geq 55$ years. Similar surveys were conducted in all other EU countries and in the European Free Trade Association states (Norway, Iceland and Switzerland), to assess countryspecific needs of employers concerning older-worker $\mathrm{OSH}$ issues. Country-specific surveys are important because a previous study showed that attitudes and actions of employers regarding the position of older workers in the EU vary by country [5].

This study has some limitations to be considered. Firstly, despite that survey answers were collected online and anonymously, provision of socially desirable answers cannot be excluded. Secondly, this study had a crosssectional design and therefore only provides descriptive results. Thirdly, it is plausible that particularly respondents who are affiliated with the research topic and already have special attention for sustainable employability in their company, completed the questionnaire. Presumably, this has influenced the results. Fourthly, despite sending a reminder, the response was rather low. Some explanations could be provided. First, the period of data collection was rather short (between April 21, 2015 and April 29, 2015). Second, most of the e-mails were sent to general e-mail addresses of the companies 
and not directly to the managers of the companies because these were mostly unavailable.

Nonetheless, this report details important new findings that may enhance both company and employee experiences with an ageing workforce. Most studies on sustainable employability of older workers have been conducted from the economic, social security, health, and disability management perspectives. This study filled the knowledge gap by assessing employers' views and needs regarding employability of older workers in Belgium.

\title{
Conclusion
}

Employers are particularly looking for tools and information about how to keep workers $\geq 55$ years old motivated and involved, adapt work nature and setting for older workers' health needs, and support an ageing workforce to maintain a good work-life balance. Addressing these topics in the country-specific e-guide may facilitate widespread implementation of sustainable employability approaches in Belgium.

\section{Competing interests}

The authors declare that they have no competing interest.

\section{Authors' contributions}

MV, YK, BV, IP, KM participated in the design of the study. MV, YK, BV, IP, KM carried out the study. MV, YK, KM performed the statistical analyses. MV, YK, KM helped to draft the manuscript. MV, YK, BV, IP, KM read and approved the final manuscript.

\section{Funding}

This study was commissioned and financed by EU-OSHA.

\section{Author details}

${ }^{1}$ Mensura Occupational Health Services, Brussels, Belgium. ${ }^{2}$ Department of Public Health, Ghent University, Ghent, Belgium. ${ }^{3}$ Milieu Ltd - Law \& Policy Consulting, Brussels, Belgium.

Received: 2 November 2015 Accepted: 19 February 2016 Published online: 28 April 2016

\section{References}

1. Europe 2020 employment indicators. In: Eurostat news release 81/2015 - 7 may 2015. http://ec.europa.eu/eurostat/documents/2995521/6823708/307052015-AP-EN.pdf/7e507ea0-43c7-452f-8e6a-b479c89d2bd6. Accessed 11 August 2015.

2. Koolhaas W. Sustainable employability of ageing workers. The development of an intervention (doctoral thesis). Rijksuniversiteit Groningen; 2014

3. Van der Klink JJ, Brouwer S, Bultmann U, Burdorf A, Schaufeli WB, Van der Wilt GJ, et al. Duurzaam inzetbaar: Een werkdefinitie [Sustainable employability; a working definition]. ZonMW.'s Gravenhage; 2010.

4. Annual Report of the Experience Fund. 2014. http://www.google.be/ url ?sa $=\mathrm{t} \& \mathrm{rct}=\mathrm{j} \& q=\&$ esrc $=\mathrm{s} \&$ source $=$ web\& $\mathrm{cd}=1 \& \mathrm{ved}=0$ CB4QFjAAahUKEwj p2OrY95vIAhXHORQKHWeYA7U\&url=http\%3A\%2F\%2Fwww.werk.be\%2F sites\%2Fdefault\%2Ffiles\%2Fonline_diensten\%2Fervaringsfonds\%2Fjv2014. pdf\&usg=AFQjCNFeA4l84sOCHQxT5A2q4Npvyc4cqw\&sig2=NUrGGR55jNtE K2OpuLn1rQ\&bvm=bv.103627116,d.bGQ. Accessed 18 September 2015.

5. Van Dalen HP, Henkens K, Schippers J. Dealing with older workers in Europe: a comparative survey of employers' attitudes and actions. J Eur Soc Policy. 2009;19:1.

\author{
Submit your next manuscript to BioMed Central \\ and we will help you at every step: \\ - We accept pre-submission inquiries \\ - Our selector tool helps you to find the most relevant journal \\ - We provide round the clock customer support \\ - Convenient online submission \\ - Thorough peer review \\ - Inclusion in PubMed and all major indexing services \\ - Maximum visibility for your research \\ Submit your manuscript at \\ www.biomedcentral.com/submit

